\title{
ELECTROLYZED SALINE... AN ALTERNATIVE TO SODIUM HYPOCHLORITE FOR ROOT CANAL IRRIGATION
}

\author{
KAVITA DUBE ${ }^{1}$, PRADEEP JAIN ${ }^{2}$
}

\author{
${ }^{1}$ Faculty of Dental Science, Pacific Academy of Higher Education and Research \\ University, Udaipur, India \\ ${ }^{2}$ Conservative Dentistry and Endodontics Department, Sri Aurobindo College of \\ Dentistry \& P.G Institute, Indore, India
}

\begin{abstract}
Objectives. The aim of this study is to evaluate electrolyzed saline, produced from a custom-made chair side apparatus for its cleaning effect on root canal walls.

Methods. A chair side apparatus has been designed to produce and dispense electrolytically activated solutions (Electrolyzed saline) for the purpose of root canal irrigation. Two different solutions, one, which is oxidizing in nature, consisting primarily of Chlorine derivatives and another, reducing in nature, consisting primarily of sodium hydroxide, are obtained. A combination of these two solutions was used for root canal irrigation in extracted teeth. Root canals were split and the samples were subjected to Scanning electron microscopic evaluation.

Results. Under the conditions of this study, electrolyzed saline significantly cleaned the root canal surfaces well, opening the dentinal tubules and removing the smear layer.

Significance. There has been a constant search for the ideal root canal irrigant. Sodium hypochlorite has been vastly used but its toxicity and storage risks are of concern. Electrolyzed saline has been produced from saline and the apparatus prepares and dispenses the solution chair side, obviating storage needs.
\end{abstract}

Keywords: irrigation, electrolyzed saline

\section{Introduction}

Thorough debridement of the root canal system is essential for the successful outcome of endodontic therapy. This is achieved by mechanical instrumentation in conjunction with irrigation.

Sodium hypochlorite $(\mathrm{NaOCl})$ is the most widely used irrigant $[1,2,3]$. It dissolves pulp tissue and is a potent anti-microbial agent. Sodium hypochlorite itself does not remove the smear layer. The combination of $\mathrm{NaOCl}$ and Ethylene diamine tetra acetic acid (EDTA) has been recommended for smear layer removal $[4,5]$. $\mathrm{NaOCl}$ when extruded beyond the apex causes severe pain, swelling and necrosis of the periapical tissues [6-8]. The use of concentrated $\mathrm{NaOCl}$ as a root canal irrigant might cause severe clinical problems when extruded into vital tissues [9]. Because of toxicity, extrusion is to be avoided [10,11], thus contraindicating its use in teeth with open apices. It is

Manuscript received: 26.06.2017

Received in revised form: 27.02.2018

Accepted: 28.02.2018

Address for correspondence: drkdube@gmail.com purchased and stored. Any spillage during handling causes bleaching of the clothes. Its vapor can be an irritant to the eyes. It is corrosive in nature, thus root canal instruments become more prone to mechanical breakdown.

The need remains for a treatment system that delivers an irrigation solution alternative to $\mathrm{NaOCl}$ having the same advantages of $\mathrm{NaOCl}$ but still overcoming its disadvantages of storage risks and toxicity caused when extruded through the tooth apex. The need further remains for the use of a more biologically acceptable root canal irrigant.

Russian scientists have developed a process whereby electro-chemically activated water ECA is produced with a unique anode-cathode system [12]. It utilizes a special flow through electrolyte module (FEM) consisting of cylindrical titanium electrodes separated by a ceramic membrane. A similar technology has been used by the Japanese to produce oxidative potential water (OPW). Both these solutions have been reported to be effective in smear layer removal [13-15]. The aim of this study is to prepare a 
similar irrigating solution by using a simpler technique by means of a compact indigenous chair side apparatus, which can prepare the irrigant in small quantities for immediate use. The efficacy of the produced irrigant electrolyzed saline in smear layer removal is evaluated.

\section{The apparatus and the irrigant}

The irrigating solution produced is an electrolytically activated solution prepared by electrolysis of an aqueous solution of salt. It includes an aqueous anion - containing and an aqueous cation - containing solution. The apparatus is a custom made electrolysis machine consisting of an anode and a cathode chamber with inbuilt platinum electrodes, a proton permeable membrane having pore sizes of 0.45 microns is positioned between the two chambers to allow ionic exchange during electrolysis (Figure 1). The electrolysis is performed at $10.8 \mathrm{~V} \mathrm{DC}, 500 \mathrm{~mA}$ current for a time period in the range of $8-20$ minutes for 50 $\mathrm{ml}$ capacity chamber. The two chambers are filled with the following solutions:

1. Distilled water in the cathode compartment (room temperature).

2. $10 \%$ Sodium chloride salt solution saline in the anode compartment (room temperature).

When a circuit is established and electric current passes through water, a series of redox reactions occur on the surface of the cathode and anode. As a result of this, new elements are formed and the composition of water and the water structure is also changed [16]. In the anode compartment, $\mathrm{NaCl}$ and $\mathrm{H} 2 \mathrm{O}$ will react and split into $\mathrm{Na}+, \mathrm{OH}-, \mathrm{H}+$ and $\mathrm{Cl}-$. As the membrane is proton permeable, $\mathrm{Na}+$ and $\mathrm{H}+$ will cross the membrane and enter into the cathode compartment. Thus, the cathode compartment contains $\mathrm{Na}^{+}, \mathrm{H}+$ and $\mathrm{OH}-. \mathrm{Na}+$ is unstable and will form $\mathrm{NaOH}$ by reacting with $\mathrm{OH}-$. Sodium hydroxide $(\mathrm{NaOH})$ is beneficial to us as it has detergent properties. This will be useful in cleansing the root canal. This solution (solution $\mathrm{B}$ ) will be reducing in nature and is alkaline with $\mathrm{pH} 10-11$, as recorded by a $\mathrm{pH}$ meter.

In the anode compartment, $\mathrm{H}+\mathrm{Cl}-, \mathrm{OH}-$ are present. Chlorine is evident in this solution by its odour. These ions may react with each other forming $\mathrm{OCl}-$, $\mathrm{HOCl}$ - and $\mathrm{Cl} 2$ etc. The exact composition cannot be known but these molecules are oxidizing in nature. It will behave similar to sodium hypochlorite. The $\mathrm{pH}$ of this solution (solution $\mathrm{A}$ ) is $6.5-7$.

Electrochemical activation synthesizes alkalis in catholyte and acids in anolyte. Their concentration is proportional to water mineralization and specific consumption of electricity in the process of synthesis. The presence of alkalis in catholyte and acids in anolyte explains the difference in the $\mathrm{pH}$ values of the solutions collected at the anode and at the cathode.

\section{Material and method}

Sixty single-rooted human teeth were collected immediately after extraction. After conventional access preparation for each tooth, a size $15 \mathrm{~K}$ file MANI was used to determine the working length. The file was introduced into the canal of each root until it just reached the apical foramen. Working length was set at $1.0 \mathrm{~mm}$ short of that position. Canal orifices were flared with Gates Glidden burs size 2.The specimens were divided into two groups of thirty teeth each.

\section{GROUP A: Sodium hypochlorite}

The root canals of group A were prepared using a series of K-type files sizes 15-60 manually in a serial technique by circumferential filing and by irrigating with a $2.5 \%$ solution of $\mathrm{NaOCl}$. Irrigation was performed after every size file. Syringe irrigation was used. After the canal was prepared to size 60 , a final flush of irrigation was carried out. A minimum of $100 \mathrm{~mL}$ of $2.5 \% \mathrm{NaOCl}$ was used in the irrigation process for each tooth.

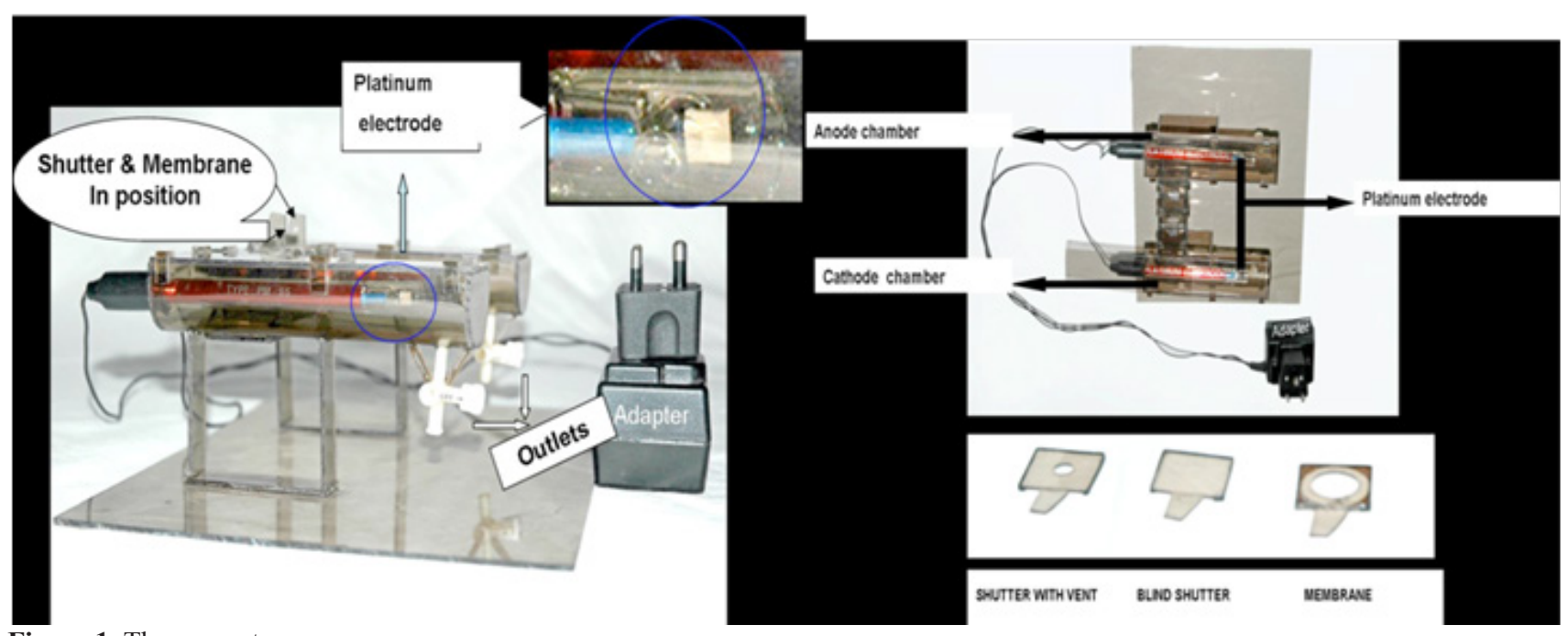

Figure 1. The apparatus. 


\section{GROUP B: Electrolyzed saline}

Root canals were prepared using the same files and the same manual technique as in group A. After the use of each size file, the canal was irrigated with solution A. A minimum of $50 \mathrm{ml}$ of solution A was used in the irrigation process of each tooth. Final flush of irrigation was carried out with $50 \mathrm{ml}$ of solution B.

\section{Preparation for SEM examination}

The canals were not dried following preparation so as to retain the existing condition of the walls. The specimens were stored in $70 \%$ ethanol in preparation for scanning electron microscopic (SEM) examination. Longitudinal grooves were cut on the buccal and lingual surfaces with a diamond disc so as not to penetrate the canal. Each root was split in two with cutting pliers and prepared for SEM observation.

The specimens were dehydrated by graded concentrations of ethanol and freeze-dried with t-butyl alcohol. They were then mounted on aluminum stubs, coated with 20-nm gold using an Ion Sputter and stored in a desiccating cabinet to maintain dryness until SEM observation.

A scanning electron microscope operated was used to view the specimens. Photomicrographs were taken of the middle and apical thirds of all specimens at a magnification of 1000. The photomicrographs were evaluated using the rating system developed by Gorman et al. [17]) by two evaluators who were blinded to the sample group. (Score 0 - No Smear layer, all tubules open; Score 1- Little smear , $>50 \%$ of tubules open; Score 2- Moderate smear layer, $<$ $50 \%$ of tubules open; Score 3 -Heavy smear layer, outline of tubule indistinguishable).

The recorded data was compiled and entered in a spreadsheet computer program (Microsoft excel 2007) and then exported to data editor page of SPSS version 15.0 (SPSS Inc., Chicago, Illinois, USA). Descriptive statistics included computation of percentages. Chi-square test (x2) was used to compare proportions for categorical data.

\section{Results}

Table I shows the comparative assessment of teeth irrigated with saline and sodium hypochlorite based on the exposure of the tubules after treatment. Eighteen of the thirty samples $(60 \%)$ treated with Electrolyzed saline were free from smear layer and more than $75 \%$ tubules exposed (Figures 3, 5). Only two samples showed a heavy smear layer on the instrumented canal wall. In some sections at higher magnification X 7500, lateral and secondary tubules were evident (Figure 4). On the contrary, none of the sample showed the same score when treated with sodium hypochlorite. Most of the samples $(73.3 \%)$ treated with sodium hypochlorite had tubules visible only in limited areas (Score 3) (Figure 2). The scores of Group B were significantly better in comparison to the scores of Group A.

Table I. Results of Scanning Electron Microscope Observation.

\begin{tabular}{|l|l|l|l|l|l|l|}
\hline Groups & Score 1 N(\%) & Score 2 N(\%) & Score 3 N(\%) & Score 4 N(\%) & Total N (\%) & p value \\
\hline $\begin{array}{l}\text { Sodium } \\
\text { Hypochlorite }\end{array}$ & 00 & $\begin{array}{l}22 \\
(10)\end{array}$ & $\begin{array}{l}05 \\
(73.3)\end{array}$ & $\begin{array}{l}30 \\
(16.7)\end{array}$ & \\
\hline $\begin{array}{l}\text { Electrolyzed } \\
\text { saline }\end{array}$ & $\begin{array}{l}18 \\
(60)\end{array}$ & $(33.3)$ & 02 & 00 & 30 & $0.001^{*}$ \\
\hline
\end{tabular}

${ }^{*} \mathrm{p}=0.001$ (highly significant); Test applied: Chi square test

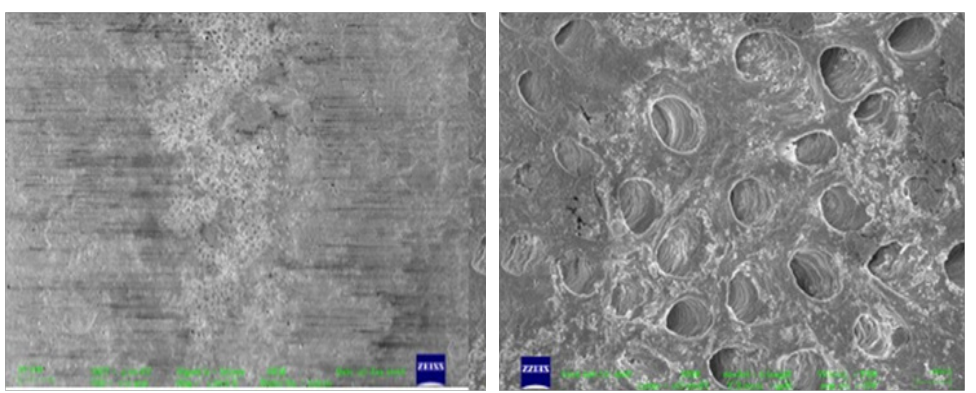

Figure 2. SEM images of samples treated with Sodium Hypochlorite (1000 $\mathrm{X}$ and $10,000 \mathrm{X})$. 

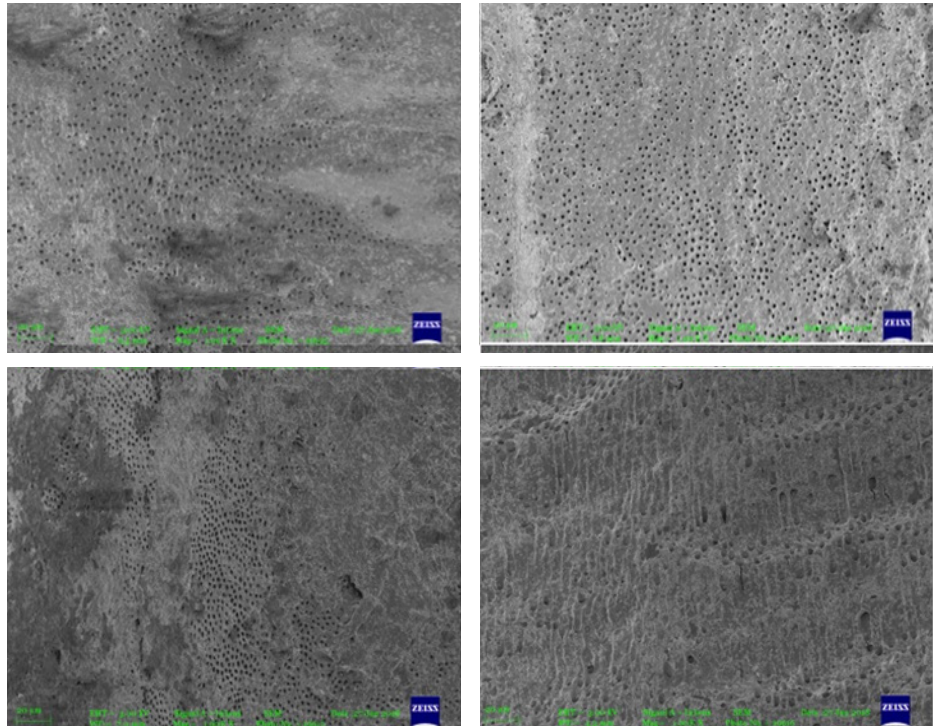

Figure 3. SEM images of samples treated with Electrolyzed saline (1000 X).
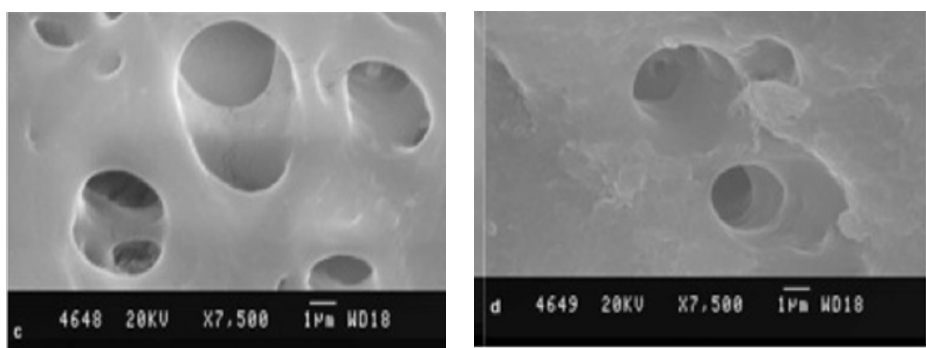

Figure 4. SEM images of samples treated with Electrolyzed saline (7500 X).
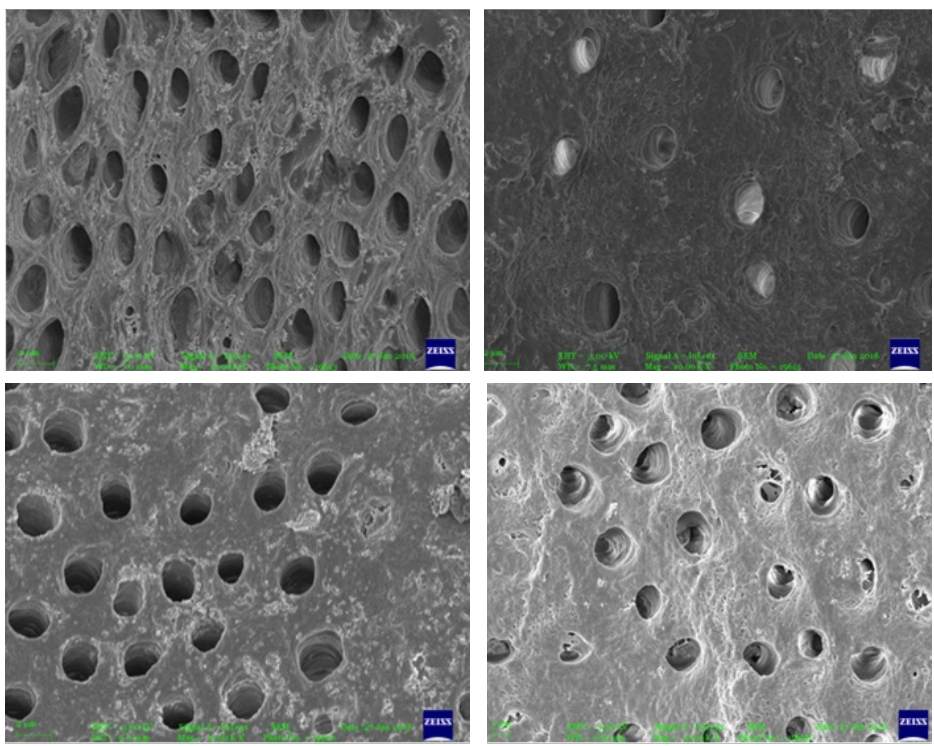

Figure 5. SEM images of samples treated with Electrolyzed saline $(10,000 \mathrm{X})$.

\section{Discussion}

Long-term success of endodontic treatment depends on the thorough debridement and effective obturation of the root canal system [18]. Theoretically all the debris and bacteria should be removed from the root canal system if long-term success is to be achieved [13]. An irrigation solution that would be effective yet harmless to human tissues would be ideal. No single irrigant has been found to dissolve organic pulpal material and demineralize the inorganic calcified portion of the canal wall. The bactericidal potential of $\mathrm{NaOCl}$ is not in doubt [19], but the fact that it is highly toxic to human tissues is of concern 
$[20,21]$. The solutions A and B are used alternatively in the root canal while cleaning and shaping, with a final rinse with solution B. Since these solutions contain molecules in their active form, the reaction in the canal will be immediate and effective. Moreover, even if the solutions enter the periapical tissues, the solutions mix with each other forming saline again, thus making these solutions biologically acceptable.

To remove or not to remove the smear layer has for long been a subject of controversy. Its advantages and disadvantages remain controversial. However, greater evidence supports its removal $[22,23]$. The organic debris present in the smear layer might constitute substrate for bacterial growth; also it may slowly disintegrate [24]. Removal of smear layer allows better adaptation of sealers to the canal wall [25]. Coronal and apical leakage is reported to be reduced after removal of smear layer [26].

Electrolyzed saline effectively cleaned the canal walls, leaving debris in only few areas. $60 \%$ of the samples showed a score $1,33.3 \%$ showed a score 2 and only $6.7 \%$ of the samples showed a score 3. On the contrary, the samples treated with sodium hypochlorite did not show clean dentinal walls. Only $10 \%$ of the samples showed a score 2 and the rest of the samples scored 3 and 4 and showed heavy smear layer on the surface. The solution collected at the cathode (solution B) is anticipated to show cleansing action due to its detergent properties owing to the presence of Sodium hydroxide and is evident from the results of SEM examination. The use of EDTA is still recommended with rotary endodontics for lubrication. Sodium hypochlorite does not remove smear layer and the same is evident from the results of this study too, so it is combined with EDTA that acts on inorganic matter as a chelating agent and removes the smear layer.

Marais evaluated the cleaning efficacy of Electrochemically activated water (ECA) and its efficacy in root canals was found to be superior to sodium hypochlorite. ECA produced cleaner root canal surfaces than did sodium hypochlorite, and removed the smear layer in large areas [13].

The Japanese have reported, favorably, on the use of oxidative potential water (OPW) for the cleaning of root canals in teeth $[14,15]$. It is not clear what OPW is, but there is some reason to believe that it may be a copy of ECA being produced from similar technology [13]. It has been used extensively in Japan for household and agricultural disinfecting purposes for its safety and bactericidal effectiveness. It exerts a rapid antimicrobial effect, decomposes to plain water instantly, and is not adsorbed to dentin. It was reported that OPW used as an irrigant during and after root canal instrumentation is as effective as $5 \%$ $\mathrm{NaOCl}$ or $17 \%$ EDTA for opening and keeping patent the dentinal tubules [15]. In another investigation, OPW irrigation by means of syringe following instrumentation with $5 \% \mathrm{NaOCl}$ showed a similar effect to that of $15 \%$ EDTA irrigation for removal of smear layer and debris [14].
Solovyeva and Dummer found ECA anolyte and catholyte to be effective in removing the smear layer and debris from the root canals [27]. Different authors have evaluated the antimicrobial effects of these similar groups of solutions and mixed results have been reported. Electrolyzed neutral water, produced by a proprietary electrolysis machine has been evaluated. It has shown to possess some bactericidal or growth-inhibitory effect against a selection of endodontic pathogens in vitro [28]. Electrolyzed water has been evaluated for antimicrobial effectiveness against bacteria isolated from root canals [29]. It did not effectively kill all microorganisms. Superoxidized water produced by using the Russian technology was found to effectively kill these same bacteria [30]. In another study, the use of ECA caused a reduction in the number of anaerobic bacteria within the root canal system, but this was not statistically significant $\mathrm{P}>0.05$ when compared to sodium hypochlorite [31]. In a recent study, the antimicrobial efficacy of ECA was found to be comparable to sodium hypochlorite solutions [32].

Electrochemically activated water, Electrolyzed neutral water and oxidative potential water are claimed to be harmless to humans. Electrolyzed saline has been produced on the similar principle. It cleaned the root canal wall surfaces in a remarkable way, removing the smear layer in large areas. It is produced from distilled water, salt and electricity by a simple electrolytic process and a compact chair side apparatus. The fact that such clean surfaces are produced is remarkable. More research is required to determine the time and amount of the solutions best suited for clinical conditions. Its activity against pathogenic microorganisms needs to be evaluated before it is clinically introduced.

\section{Conclusion}

Under the conditions of this study, Electrolyzed saline significantly cleaned the root canal surfaces well, opening the dentinal tubules and removing the smear layer.

\section{References}

1. Cheung GS, Stock CJ. In vitro cleaning ability of root canal irrigants with and without endosonics. Int Endod J. 1993;26:334343.

2. Gulabivala K, Stock CJR. Preparation of the root canal. In: Stock CJR, Gulabivala K, Walker RT, Goodman JR, eds. Color Atlas and Text of Endodontics 1995;2nd edn. Mosby-Wolfe, pp 97-144.

3. Johnson W.T, Noblett W.C.Cleaning and shaping. In: Torabinejad M, Walton RE, eds. Endodontics principles and practice 2009, 4th edn. Noida, India. Saunders, pp 258-86.

4. Yamada RS, Armas A, Goldman M, Lin PS. A scanning electron microscopic comparison of a high volume final flush with several irrigating solutions: Part 3. J Endod. 1983;9:137-142.

5. Baumgartner JC, Mader CL. A scanning electron microscopic evaluation of four root canal irrigation regimens. J Endod. 1987; 13:147-157.

6. Brown DC, Moore BK, Brown CE Jr, Newton CW. An in 
vitro study of apical extrusion of sodium hypochlorite during endodontic canal preparation. J Endod. 1995; 21:587-591.

7. Cymbler DM, Ardakani P. Sodium hypochlorite injection into periapical tissues. Dent Update. 1994;21:345-346.

8. Calişkan MK, Türkün $\mathrm{M}$, Alper S. Allergy to sodium hypochlorite during root canal therapy: a case report. Int Endod J. 1994;27:163-167.

9. Gernhardt CR, Eppendorf K, Kozlowski A, Brandt M. Toxicity of concentrated sodium hypochlorite used as an endodontic irrigant. Int Endod J. 2004;37:272-280.

10. Pashley EL, Birdsong NL, Bowman K, Pashley DH. Cytotoxic effect of $\mathrm{NaOCl}$ on vital tissue. J Endod. 1985;11(12):525-528.

11. Hülsmann M, Hahn W. Complications during root canal irrigation--literature review and case reports. Int Endod J. 2000;33:186-193.

12. Leonov BI. Electrochemical activation of water and aqueous solutions: past, present and future. In: Proceedings of the First International Symposium on Electrochemical Activation in Medicine, Agriculture and Industry, Moscow, Russia 1997; 11-27. 13. Marais JT. Cleaning efficacy of a new root canal irrigation solution: a preliminary evaluation. Int Endod J. 2000;33:320-325. 14. Hata G, Hayami S, Weine FS, Toda T. Effectiveness of oxidative potential water as a root canal irrigant. Int Endod J. 2001;34:308-317.

15. Hata G, Uemura M, Weine FS, Toda T. Removal of smear layer in the root canal using oxidative potential water. J Endod. 1996;22:643-645.

16. Ignatov I, Mosin OV, Gluhchev G, Karadzhov S, Miloshev G, Ivanov $\mathrm{N}$. The evaluation of the mathematical model of interaction of electrochemically activated water solutions (anolyte and catholyte) with water. European Reviews of Chemical Research. 2015;4(2):72-86.

17. Gorman MC, Steiman HR, Gartner AH. Scanning electron microscopic evaluation of root-end preparations. J Endod. 1995;21:113-117.

18. Weine FS. Endodontic therapy. 4th ed. St. Louis: CV Mosby, 1989, pp 344- 50.

19. Siqueira JF Jr, Batista MM, Fraga RC, de Uzeda M. Antibacterial effects of endodontic irrigants on black-pigmented gram-negative anaerobes and facultative bacteria. J Endod. 1998;24:414-416.

20. Spangberg L, Engström B, Langeland K. Biologic effects of dental materials. 3. Toxicity and antimicrobial effect of endodontic antiseptics in vitro. Oral Surg Oral Med Oral Pathol. 1973;36:856-871.

21. Thé SD, Maltha JC, Plasschaert AJ. Reactions of guinea pig subcutaneous connective tissue following exposure to sodium hypochlorite. Oral Surg Oral Med Oral Pathol. 1980;49:460-466. 22. Torabinejad M, Handysides R, Khademi AA, Bakland LK. Clinical implications of the smear layer in endodontics: a review. Oral Surg Oral Med Oral Pathol Oral Radiol Endod. 2002;94:658666.

23. Clarke-Holke D, Drake D, Walton R, Rivera E, Guthmiller JM. Bacterial penetration through canals of endodontically treated teeth in the presence or absence of smear layer. J Dent. 2003;31:275-281.

24. Delivanis PD, Mattison GD, Mendel RW. The survivability of F43 strain of Streptococcus sanguis in root canals filled with gutta-percha and Procosol cement. J Endod. 1983;9:407-410.

25. Wennberg A, Orstavik D. Adhesion of root canal sealers to bovine dentine and gutta-percha. Int Endod J. 1990;23:13-19.

26. Leonard JE, Gutmann JL, Guo IY. Apical and coronal seal of roots obturated with dentine bonding agent and resin. Int Endod J. 1996;29:76-83.

27. Solovyeva AM, Dummer PM. Cleaning effectiveness of root canal irrigation with electrochemically activated anolyte and catholyte solutions: a pilot study. Int Endod J. 2000;33:494-504.

28. Horiba N, Hiratsuka K, Onoe T, Yoshida T, Suzuki K, Matsumoto $\mathrm{T}$, et al. Bactericidal effect of electrolyzed neutral water on bacteria isolated from infected root canals. Oral Surg Oral Med Oral Pathol Oral Radiol Endod. 1999;87:83-87.

29. Shimizu Y, Furusawa T. Killing action of virus, bacteria and fungus by oxidative potential water induced by electrolysis. $\mathrm{J}$ Dent Med. 1992;36:1055-1060.

30. Selkon JB, Babb JR, Morris R. Evaluation of the antimicrobial activity of new super-oxidized water, Sterilox, for the disinfection of endoscopes. J Hosp Infect. 1999;41:59-70.

31. Marais JT, Williams WP. Antimicrobial effectiveness of electro-chemically activated water as an endodontic irrigation solution. Int Endod J. 2001;34:237-243.

32. Lata S, Mohanty SK, Pradhan PK, Patri G, Sinha SP, Agrawal P. Anti bacterial Effectiveness of Electro- Chemically Activated (ECA) Water as a Root Canal Irrigant- An In-vitro Comparative Study. J Clin Diagn Res. 2016;10:ZC138-ZC142. 